\title{
UJI DAYA HASIL BEBERAPA GALUR KEDELAI (Glycine max[L.] Merrill) HASIL PERSILANGAN WILIS DAN MIg 2521
}

\author{
Nyimas Sa'diyah, Jefri Zulkarnain \& Maimun Barmawi \\ Jurusan Agroteknologi Fakultas Pertanian Universitas lampung, \\ Jl. Prof. Soemantri Brodjonegoro, No. 1, Bandar Lampung 35145 \\ Email: nyimas_diyah@yahoo.com
}

\begin{abstract}
ABSTRAK
Meningkatnya kebutuhan kedelai sepanjang tahun menyebabkan produksi kedelai harus ditingkatkan. Cara untuk meningkatkan produksi kedelai adalah dengan cara pemuliaan tanaman yang bertujuan menghasilkan varietas unggul. Untuk mendapatkan varietas unggul diawali dengan menyilangkan dua tetua yang memiliki keunggulan dan karakteristik yang berbeda. Tujuan penelitian ini adalah mengevaluasi 14 galur $\mathrm{F}_{5}$ kedelai hasil persilangan Wilis x Mlg 2521 yang memiliki produksi lebih tinggi dibandingkan dengan pembanding Wilis dan Mlg 2521. Penelitian ini dilaksanakan pada bulan Oktober 2013 sampai dengan bulan Januari 2014 dan menggunakan benih kedelai $\mathrm{F}_{5}$ persilangan varietas Wilis x MLg 2521 dan benih tetua Wilis dan Mlg 2521. Perlakuan disusun dalam rancangan kelompok teracak sempurna dengan dua ulangan. Pemisahan nilai tengah menggunakan uji LSI pada $\alpha$ 0,05. Hasil penelitian ini terdapat satu nomor harapan, yaitu nomor 7.199.4 yang memiliki bobot biji per tanaman 39,16 g atau 3,92 ton/ha yang melebihi bobot biji per tanaman tetua Wilis, selain itu nomor 7.199.4 memiliki umur berbunga $47,50 \mathrm{hst}$, umur panen 109,00 hst, tinggi tanaman $95,17 \mathrm{~cm}$, jumlah cabang 5,42 buah, total jumlah polong 172,00 buah dan memiliki bobot 100 butir $11,31 \mathrm{~g}$.
\end{abstract}

Kata kunci: generasi $\mathrm{F}_{5}$, kedelai, uji daya hasil

\section{PENDAHULUAN}

Berdasarkan data Badan Pusat Statistik (BPS) 2013, produksi kedelai nasional hanya 779.992 ton. Stok kedelai di Indonesia pada tahun 2013 mengalami defisit sebanyak 1,3 juta ton. Pasalnya, produksi kedelai hanya sebesar 807,6 ribu ton, adapun kebutuhan masyarakat mencapai 2.115,7 ribu ton. Untuk menutupi defisit tersebut, sampai dengan bulan September 2013 Kementan terpaksa mengimpor sebanyak 1,2 Juta ton kedelai dari sejumlah Negara untuk memenuhi kebutuhan industri tahu - tempe (Kementan, 2013).

Terdapat berbagai cara untuk meningkatkan produksi kedelai salah satunya dengan cara pemuliaan tanaman, yang bertujuan menghasilkan varietas unggul. Untuk mendapatkan varietas unggul dapat diawali dengan menyilangkan dua tetua yang memiliki keunggulan dan karakteristik yang berbeda. Pada penelitian ini menggunakan persilangan antara Wilis dan Mlg 2521. Varietas Wilis adalah varietas yang dibudidayakan petani dan memiliki produksi tinggi tetapi rentan terhadap penyakit yang disebabkan oleh soybean stunt virus (SSV)dan cowpea mild mottle virus (CPMMV). Menurut Asadi (2003) Mlg 2521 tahan terhadap SSV dan CPMMV tetapi memiliki produksi yang rendah.
Pada generasi $\mathrm{F}_{2}$ ditanam 12 genotipe yang terpilih (Yantama, 2012). Dari 12 genotipe tersebut terdapat satu nomor, yaitu nomor 7 yang dilanjutkan oleh Sari (2013).Benih $\mathrm{F}_{3}$ genotipe no 7 yang diuji oleh Sari (2013) merupakan langkah selanjutnya untuk mengestimasi keragaman fenotipe dan genotipe serta heritabilitas dalam arti luas. Hasil penelitian Sari (2013) menunjukkan bahwa keragaman genetik dan fenotipe untuk berbagai karakter agronomi termasuk ke dalam kriteria sempit sampai luas. Besaran nilai hertabilitas dalam arti luas termasuk ke dalam kriteria sedang sampai tinggi. Juga diperoleh nomor - nomor harapan yang produktivitasnya lebih tinggi dibandingkan dengan tetua Wilis dan Mlg 2521.

Pada generasi $\mathrm{F}_{4}$ diuji sebanyak 25 genotipe harapan yang dipilih berdasarkan bobot biji per tanaman dan bobot 100 butir. Pengujian dilakukan oleh Barmawi dkk.(2013). Hasil pengujian menunjukkan bahwa kergaman genetik dan fenotipe untuk berbagai karakter yang diamati termasuk ke dalam kriteria sempit sampai luas dan besaran nilai heritabilitas dalam arti luas termasuk ke dalam kriteria rendah sampai tinggi. Diperoleh 14 genotipe harapan yang memiliki nilai tengah bobot biji per tanaman dan bobot 100 butir yang lebih berat dibandingkan dengan dua tetuanya. Selanjutnya dilakukan pengujian dari genotipe-genotipe yang terpilih 
pada generasi $\mathrm{F}_{4}$. Tujuan dari penelitian ini adalah mengevaluasi galur-galur $\mathrm{F}_{5}$ tanaman kedelai hasil persilangan Wilis x Mlg 2521 yang memiliki produksi lebih tinggi dibandingkan dengan pembanding(Wilis dan Mlg 2521).

\section{BAHAN DAN METODE}

Penelitian ini dilaksanakan di Laboratorium Lapang Terpadu Fakultas Pertanian, Universitas Lampung, Gedung Meneng, Bandar Lampung dan Laboratorium Benih dan Pemuliaan Tanaman Fakultas Pertanian, Universitas Lampung pada bulan Oktober 2013 hingga Januari 2014. Bahan yang digunakan dalam penelitian ini adalah kedelai $\mathrm{F}_{5}$ hasil persilangan varietas Wilis x MLg 2521 dan benih varietas Wilis dan MLg 2521 sebagai pembanding.

Percobaan menggunakan rancangan kelompok teracak sempurna, yang terdiri atas dua ulangan. Jarak antar tanaman $20 \mathrm{~cm}$ dan jarak antar genotipe $50 \mathrm{~cm}$. Data selanjutnya dianalisis ragam dan dilanjutkan dengan uji LSI (Least Significance Increase) dengan taraf 5\%.

\section{HASIL DAN PEMBAHASAN}

Karakter umur berbunga pada seluruh nomor genotipe yang diuji berkisar 46,5 - 48,85 hst dengan rata - rata 47,32 hst, sedangkan varietas pembanding Wilis dan Mlg 2521 masing - masing berbunga pada 47,83 hst dan 47 hst. Hasil uji LSI menunjukkan bahwa hanya genotipe nomor 7.24.1 yang memiliki umur berbunga lebih lama yaitu 48,85 hst dibandingkan varietas pembanding Wilis, sedangkan genotipe nomor 7.24.1, 7.90.2, 7.24.1, 7.199.4, dan 7.73.3 memiliki umur berbunga yang lebih lama dibandingkan dengan varietas pembanding Mlg 2521 (Tabel 1).

Umur panen pada semua genotipe yang diuji berkisar 103,37 - 109,91 hst dengan rata - rata 106,64 hst, sedangkan varietas pembanding Wilis dan Mlg 2521 masing - masing memiliki umur panen yang sama 109 hst. Genotipe nomor 7.24.1 dan 7.61.4 dengan rata rata masing - masing 109,91 dan 112 hst memiliki umur panen lebih lama dibandingkan dengan varietas pembanding Wilis maupun Mlg 2521 (Tabel 1).

Menurut Adie dan Krisnawati (2007), umur panen di Indonesia terbagi atas tiga golongan yaitu varietas berumur genjah ( 78 - 85 hari), sedang ( 86 - 95 hari), dan dalam (>95 hari). Berdasarkan pengelompokan tersebut, umur panen semua genotipe kedelai $\mathrm{F}_{5}$ yang diuji berkisar antara 109,91 dan 112 hst dengan rata rata 108,8 hst sehingga dikategorikan sebagai kedelai berumur dalam ( $>95$ hari).Kedua varietas pembanding memiliki umur panen yang termasuk ke dalam kriteria dalam. Menurut deskripsi varietas, varietas Wilis memiliki umur panen dalam yaitu 85 - 90 hst. Pada penelitian ini varietas Wilis memiliki umur panen 109 hst.

Menurut Sumpena dkk (2013), bahwa umur panen ditentukan oleh faktor genetik dan kondisi lingkungan seperti iklim, elevasi dan musim tanam. Selain itu, umur panen ditentukan juga oleh adanya interaksi antara lingkungan dan varietas. Lingkungan yang kurang menguntungkan atau kurang menunjang pertumbuhan tanaman kedelai akan memperpendek masa pertumbuhan vegetatif dan mempercepat masa pertumbuhan generatif, mulai dari saat pembungaan sampai dengan saat panen.

Semua genotipe dan varietas pembanding Wilis yang diuji memiliki tipe tumbuh determinate yaitu tanaman akan mengakhiri pertumbuhan vegetatif pada saat tanaman mulai tumbuh bunga, sedangkan varietas pembanding Mlg 2521 memiliki tipe tumbuh indeterminate, yaitu pada saat tanaman berbunga pertumbuhan vegetatif masih berlangsung. Genotipegenotipe kedelai $\mathrm{F}_{5}$ yang diuji memiliki tinggi tanaman berkisar 74,48 - 97,07 cm. Rata - rata tinggi tanaman varietas pembanding yaitu Wilis dan Mlg 2521 adalah 70,75 dan 77,5 cm. Genotipe nomor 7.64.1, 7.83.5, 7.61.1, dan 7.44.3 memiliki tinggi tanaman yang lebih pendek dibandingkan dengan varietas pembanding Wilis, sedangkan genotipe nomor 7.64.1, 7.261.1, 7.83.5, 7.61.1, 7.44.3, dan 7.90.2 memiliki rata - rata tidak lebih tinggi dibandingkan rata - rata pembanding Mlg 2521.

Menurut Arsyat et al. (2007), tipe tanaman kedelai yang ideal (plant-ideotipe) yang berdaya hasil tinggi dan dianggap sesuai pada lingkungan yang optimum antara lain memiliki tinggi tanaman berkisar $60-70 \mathrm{~cm}$. Genotipe - genotipe kedelai $\mathrm{F}_{5}$ dalam penelitian yang memiliki tinggi tanaman yang ideal adalah genotipe nomor 7.64.1, 7.83.5, 7.61.1, 7.44.3. Pada penelitian ini tinggi tanaman pada varietas pembanding Wilis dan Mlg 2521 merupakan kriteria ideal.

Karakter jumlah cabang pada genotipe - genotipe kedelai $\mathrm{F}_{5}$ yang diuji memiliki rata - rata 5,60 cabang dengan data berkisar 4,85-6,36 cabang. Genotipe nomor 7.24.1 memiliki rata - rata jumlah cabang tertinggi yaitu 6,36 cabang, sedangkan genotipe nomor 7.261.1 merupakan genotipe yang memiliki jumlah cabang terendah yaitu 4,85. Di antara dua varietas pembanding Wilis dan Mlg 2521, varietas Wilis memiliki rata - rata jumlah cabang yang lebih sedikit dari pada Mlg 2521 yaitu 4,45 sedangkan Mlg 2521 adalah 5,5 (Tabel 1).

Jumlah cabang yang dimiliki semua genotipe yang diuji tidak sama dengan jumlah cabang varietas 
Tabel 1.Uji rata - rata karakter umur berbunga, umur panen, tinggi tanaman, dan jumlah cabang dengan pembanding tetua Wilis dan Mlg 2521.

\begin{tabular}{lcccc}
\hline & Umur berbunga (hst) & Umur panen & Tinggi tanaman & Jumlah cabang \\
\hline t0,05;14 & 1753,00 & 1753,00 & 1753,00 & 1753,00 \\
MSE & 0,06 & 0,00 & 34,77 & 0,24 \\
LSI & 0,42 & 0,04 & 10,34 & 0,86 \\
Rata-rata & 47,83 & 109,00 & 70,75 & 4,46 \\
Wilis & & & & 5,32 \\
Rata-rata & 48,25 & 109,04 & 81,09 & \\
Wilis+LSI & & & & 5,50 \\
Rata-rata & 47,00 & 109,00 & 77,50 & \\
Mlg 2521 & & & & 6,36 \\
Rata-rata & 47,42 & 109,00 & 87,84 & \\
Mlg & & & & \\
2521+LSI & & & & \\
\hline
\end{tabular}

\begin{tabular}{llllllllllllll}
\hline $\begin{array}{l}\text { No. } \\
\text { Genotipe }\end{array}$ & $\begin{array}{l}\text { Nilai } \\
\text { tengah }\end{array}$ & Wilis & $\begin{array}{l}\text { Mlg } \\
2521\end{array}$ & $\begin{array}{l}\text { Nilai } \\
\text { tengah }\end{array}$ & Wilis & $\begin{array}{l}\text { Mlg } \\
2521\end{array}$ & $\begin{array}{l}\text { Nilai } \\
\text { tengah }\end{array}$ & Wilis & $\begin{array}{l}\text { Mlg } \\
2521\end{array}$ & $\begin{array}{l}\text { Nilai } \\
\text { tengah }\end{array}$ & Wilis & $\begin{array}{l}\text { Mlg } \\
2521\end{array}$ \\
\hline 7.144 .2 & 46,50 & - & - & 103,380 & - & - & 91,50 & + & + & 5,750 & + & - \\
7.64 .1 & 47,00 & - & - & 109,000 & - & - & 79,95 & - & - & 5,370 & + & - \\
7.24 .1 & 48,85 & + & + & 109,920 & + & + & 94,38 & + & + & 6,370 & + & + \\
7.61 .4 & 47,00 & - & - & 112,000 & + & + & 88,01 & + & + & 5,170 & - & - \\
7.141 .5 & 47,17 & - & - & 109,000 & - & - & 96,83 & + & + & 5,420 & + & - \\
7.261 .1 & 47,00 & - & - & 109,000 & - & - & 84,00 & + & - & 4,860 & - & - \\
7.83 .5 & 47,00 & - & - & 109,000 & - & - & 74,49 & - & - & 5,250 & - & - \\
7.192 .1 & 47,20 & - & - & 109,000 & - & - & 96,30 & + & + & 5,400 & + & - \\
7.61 .1 & 47,00 & - & - & 109,000 & - & - & 79,40 & - & - & 4,580 & - & - \\
7.44 .3 & 47,00 & - & - & 109,000 & - & - & 76,25 & - & - & 5,000 & - & - \\
7.90 .2 & 47,79 & - & + & 109,000 & - & - & 87,57 & + & - & 5,070 & - & - \\
7.23 .3 & 48,14 & - & + & 109,000 & - & - & 97,07 & + & + & 5,210 & - & - \\
7.199 .4 & 47,50 & - & + & 109,000 & - & - & 95,17 & + & + & 5,420 & + & - \\
7.73 .3 & 47,43 & - & + & 109,000 & - & - & 93,67 & + & + & 6,140 & + & - \\
\hline
\end{tabular}

Keterangan: + = Lebih tinggi daripada varietas Wilis + LSI pada taraf 5\%, - = Lebih rendah daripada varietas Wilis + LSI pada taraf $5 \%$.

pembanding. Genotipe nomor 7.144.2, 7.64.1, 7.141.5, 7.92.1, 7.199.4 dan 7.73.3 memiliki jumlah cabang lebih banyak dibandingkan dengan varietas Wilis, sedangkan hanya genotipe nomor 7.24.1 yang memiliki jumlah cabang lebih banyak dibandingkan dengan Mlg 2521 (Tabel 1). Dengan meningkatnya jumlah cabang, maka jumlah daun akan bertambah sehingga aktivitas dan proses fotosintesis menjadi lebih baik. Kondisi tersebut menyebabkan fotosintat akan meningkat (Pandiangan, 2012) dan kemudian ditransportasikan menuju pengisian polong dalam cabang tersebut.

Menurut Arsyat et al. (2007), bahwa tipe tanaman kedelai ideal (plant-ideotipe) berdaya hasil tinggi dan dianggap sesuai memiliki percabangan yang cukup 
Tabel 2.Uji rata - rata karakter jumlah polong, bobot 100 butir dan bobot biji per tanaman dengan pembanding tetua Wilis dan Mlg 2521.

\begin{tabular}{|c|c|c|c|c|c|c|c|c|c|}
\hline & \multicolumn{3}{|c|}{ Jumlah polong } & \multicolumn{3}{|c|}{ Bobot 100 butir } & \multicolumn{3}{|c|}{ Bobot biji per tanaman } \\
\hline $\mathrm{t} 0,05 ; 14$ & \multicolumn{3}{|c|}{1753,00} & \multicolumn{3}{|c|}{1753,00} & \multicolumn{3}{|c|}{1753,00} \\
\hline MSE & \multicolumn{3}{|c|}{508,36} & \multicolumn{3}{|c|}{0,19} & \multicolumn{3}{|c|}{23,98} \\
\hline LSI & \multicolumn{3}{|c|}{39,52} & \multicolumn{3}{|c|}{0,77} & \multicolumn{3}{|c|}{8,58} \\
\hline $\begin{array}{l}\text { Rata-rata } \\
\text { Wilis }\end{array}$ & \multicolumn{3}{|c|}{146,29} & \multicolumn{3}{|c|}{11,69} & \multicolumn{3}{|c|}{30,26} \\
\hline $\begin{array}{l}\text { Rata-rata } \\
\text { Wilis+LSI }\end{array}$ & \multicolumn{3}{|c|}{185,81} & \multicolumn{3}{|c|}{12,46} & \multicolumn{3}{|c|}{38,84} \\
\hline $\begin{array}{l}\text { Rata-rata } \\
\text { Mlg } 2521\end{array}$ & \multicolumn{3}{|c|}{126,17} & \multicolumn{3}{|c|}{11,31} & \multicolumn{3}{|c|}{18,97} \\
\hline $\begin{array}{l}\text { Rata-rata } \\
\text { Mlg } \\
2521+\text { LSI }\end{array}$ & \multicolumn{3}{|c|}{165,69} & \multicolumn{3}{|c|}{12,08} & \multicolumn{3}{|c|}{27,56} \\
\hline No. Genotipe & $\begin{array}{l}\text { Nilai } \\
\text { tengah }\end{array}$ & Wilis & $\begin{array}{l}\text { Mlg } \\
2521\end{array}$ & $\begin{array}{l}\text { Nilai } \\
\text { tengah }\end{array}$ & Wilis & $\begin{array}{l}\mathrm{Mlg} \\
2521\end{array}$ & $\begin{array}{l}\text { Nilai } \\
\text { tengah }\end{array}$ & Wilis & $\begin{array}{l}\text { Mlg } \\
2521\end{array}$ \\
\hline 7.144 .2 & 132,38 & - & - & 12,06 & - & - & 31,28 & - & + \\
\hline 7.64 .1 & 142,45 & - & - & 12,74 & + & + & 35,20 & - & + \\
\hline 7.24.1 & 175,43 & - & + & 11,03 & - & - & 37,00 & - & + \\
\hline 7.61 .4 & 132,80 & - & - & 10,78 & - & - & 29,73 & - & + \\
\hline 7.141.5 & 131,83 & - & - & 12,57 & + & + & 31,58 & - & + \\
\hline 7.261.1 & 142,21 & - & - & 11,35 & - & - & 28,11 & - & + \\
\hline 7.83 .5 & 131,21 & - & - & 13,35 & + & + & 34,32 & - & + \\
\hline 7.192 .1 & 159,73 & - & - & 11,07 & - & - & 34,90 & - & + \\
\hline 7.61 .1 & 130,15 & - & - & 11,15 & - & - & 28,70 & - & + \\
\hline 7.44 .3 & 115,96 & - & - & 10,45 & - & - & 25,24 & - & - \\
\hline 7.90 .2 & 143,29 & - & - & 10,51 & - & - & 29,83 & - & + \\
\hline 7.23 .3 & 164,57 & - & - & 11,23 & - & - & 34,52 & - & + \\
\hline 7.199 .4 & 172,00 & - & + & 11,31 & - & - & 39,16 & + & + \\
\hline 7.73 .3 & 145,14 & - & - & 11,39 & - & - & 31,77 & - & + \\
\hline
\end{tabular}

Keterangan: + = Lebih tinggi daripada varietas Wilis + LSI pada taraf 5\%, - = Lebih rendah daripada varietas Wilis + LSI pada taraf $5 \%$.

banyak adalah 4 - 5 cabang.Nomor - nomor genotipe kedelai yang tidak memenuhi kriteria ideal adalah genotipe nomor 7.24.1 dan 7.73.3 dengan rata ratacabang masing - masing 6,36 dan 6,14 .

Total jumlah polong merupakan penentu hasil biji pada semua varietas kedelai yang diuji. Hal tersebut sesuai dengan deskripsi penelitian bahwa varietas Wilis memiliki hasil lebih banyak dibandingkan dengan Mlg 2521. Total jumlah polong yang diamati memiliki rata rata berkisar 115,95 - 175,43 polong. Untuk rata - rata dari masing - masing varietas pembanding Wilis dan Mlg 2521 adalah 146,29 dan 126,16. Hasil pengujian menunjukan bahwa tidak ada nomor genotipe yang memiliki jumlah polong lebih banyak daripada Wilis, 
sedangkan genotipe yang memiliki polong lebih banyak daripada Mlg 2521 adalah genotipe nomor 7.24.1 dan 7.199.4 (Tabel 2)

Ohorella (2011) menyatakan bahwa semakin banyak jumlah polong tiap tanaman berpeluang menyumbang hasil yang lebih tinggi per tanaman. Jumlah polong sangat dipengaruhi saat stadia pembentukan polong. Menurut Evita (2010), pembentukan polong merupakan suatu stadia yang sangat peka terhadap kekurangan air, terutama selama 30 hari. Kekurangan air selama periode pembentukan polong akan menghasilkan sedikit polong berisi.

Gardner et al. (1991) menyatakan bahwa pada saat pengisian polong, maka polong akan menjadi daerah penyaluran asimilasi. Sebagian besar asimilasi akan digunakan untuk meningkatkan bobot biji. Pembentukan polong tergantung pada tingkat kelembaban tanah yang tinggi dan penyediaan unsur hara.

Bobot 100 butir kedelai $\mathrm{F}_{5}$ yang diuji untuk semua genotipe memiliki kisaran rata - rata 10,45 - 12,74 g dengan rata - rata $11,4 \mathrm{~g}$, sedangkan varietas pembanding Wilis dan Mlg 2521 memiliki rata - rata masing - masing 11,69 dan 11,36 g. Genotipe nomor 7.64.1, 7.141.5, dan 7.83.5 merupakan nomor genotipe yang memiliki bobot 100 butir melebihi Wilis dan Mlg 2521. Bobot 100 butir menggambarkan ukuran biji kedelai (Tabel 2).

Ukuran biji dipengaruhi oleh ukuran polong suatu tanaman. Hartoko (2005) dalam Pandiangan (2012) menyatakan bahwa polong kecil mengasilkan biji kecil karena keterbatasan dinding polong dan berakibat ukuran sel menjadi lebih sedikit dan lebih kecil.Untuk itu, Adie dan Krisnawati (2007) mengelompokkan ukuran biji kedelai menjadi 3 kelompok yaitu biji berukuran kecil ( $<10 \mathrm{~g} / 100$ butir), sedang $(10-14 \mathrm{~g} / 100$ butir), dan besar (>14 g/100 butir).Berdasarkan pengelompokan tersebut, semua nomor genotipe kedelai $\mathrm{F}_{5}$ yang diuji termasuk ke dalam karakter biji sedang karena memiliki kisaran $11,69-11,36 \mathrm{~g} / 100$ butir.

Ukuran biji banyak dipengaruhi oleh faktor genetik, sistem budidaya, genotipe, dan varietas tanaman itu sendiri (Ohorella, 2011).Bila dikaitkan dengan jumlah polong, varietas dan nomor genotipe yang berpolong banyak ukuran bijinya kecil, sebaliknya jumlah polong yang rendah ukuran biji lebih besar. Hal ini juga terlihat pada genotipe nomor 7.24.1, dan 7.199.4 yang memiliki jumlah polong lebih banyak berkisar 164,57 - 175,43 buah namun bobot 100 butir relatif lebih rendah, yaitu $11,03 \mathrm{~g}-11,31 \mathrm{~g}$, sebaliknya genotipe nomor 7.64.1, 7.141.5, dan 7.83.5 yang memiliki bobot 100 butir yang berat berkisar 12,06 $\mathrm{g}-13,35 \mathrm{~g}$ namun memiliki jumlah polong relatif lebih sedikit, yaitu 131,21 - 132,38 buah (Tabel 2).
Menurut Susanto (2004), bahwa semakin tinggi bobot 100 butir dan jumlah polong per tanaman yang dicapai tanaman maka semakin tinggi produksi yang dihasilkan. Selain itu faktor lain yang turut berpengaruh dalam produksi suatu tanaman adalah lingkungan dan iklim. Namun, setiap galur/varietas tanaman memiliki kemampuan daya adaptasi yang berbeda sehingga tanaman kedelai yang unggul di suatu daerah belum tentu unggul pada daerah lain karena sifat tanah dan iklim yang berbeda (Baco et al., 1987 dalam Sumpena dkk., 2013).

Karakter tinggi tanaman dan bobot biji per tanaman seluruh nomor genotipe yang diuji memiliki rata - rata melebihi dari kedua varietas pembanding Wilis dan Mlg 2521, sedangkan semua genotipe yang diuji jumlah polong dan bobot 100 biji tanaman memiliki rata - rata melebihi Mlg 2521 tetapi tidak lebih besar daripada Wilis. Umur berbunga kedelai hasil persilangan generasi $\mathrm{F}_{5}$ Wilis dan Mlg 2521 memiliki waktu berbunga lebih awal dari Wilis tetapi tidak lebih cepat dibandingkan Mlg 2521, sedangkan pada karakter umur panen seluruh genotipe yang diuji memiliki waktu panen lebih cepat dibandingkan Wilis dan Mlg 2521. Hanya pada karakter jumlah cabang Mlg 2521 memiliki rata - rata melebihi seluruh genotipe yang diuji dan Wilis (Wilis).

Karakter bobot biji per tanaman merupakan karakter penting yang dapat digunakan untuk kriteria seleksi secara langsung guna mendapatkan galur yang berdaya hasil tinggi.Karakter bobot biji menunjukkan korelasi positif dengan potensi hasil (ton/ha). Semua genotipe yang diuji mempunyai bobot biji per tanaman berkisar 25,24 - 39,15 g dengan rata - rata 32,23 g, bobot biji per tanaman tersebut apabila dikonversikan ke dalam ton adalah 3,22 ton/ha. Wilis dan Mlg 2521 sebagai varietas pembanding memiliki rata - rata bobot biji per tanaman, yaitu 30,25 g dan 18,97 g dan apabila dikonversi ke ton/ha, maka masing - masing 3,02 ton/ ha dan 1,87 ton/ha. Hanya genotipe nomor 7.199.4 yang memiliki bobot biji per tanaman yang melebihi varietas pembanding Wilis, sedangkan dengan pembanding varietas Mlg 2521 hanya genotipe nomor 7.44.3 memiliki bobot biji per tanaman lebih ringan. Pada genotipe nomor 7.44.3 juga menunjukkan hasil jumlah cabang, jumlah polong dan bobot 100 butir yang tidak melebihi varietas pembanding Mlg 2521 (Tabel 1 dan 2).

Hasil penelitian Siagian (2014) menunjukkan bahwa total jumlah polong per tanaman dan bobot 100 butir berkorelasi dengan bobot biji per tanaman berturut - turut sebesar $\left(0,81^{*}\right)$ dan $\left(0,29^{*}\right)$. Dari hasil penelitian ini dapat dipilih genotipe harapan, yaitu genotipe nomor 7.199.4, 7.24.1, 7.64.1, 7.83.5, 7.192.1, 
dan 7.23.3.Genotipe nomor 7.199.4 memiliki bobot biji per tanaman terbanyak dibandingkan dengan seluruh genotipe yang diuji. Genotipe - genotipe tersebut dipilih karena memiliki total jumlah polong yang lebih banyak dan ukuran biji termasuk kriteria sedang dibandingkan dengan tetuanya. Total jumlah polong yang banyak dan bobot 100 butir yang berat mengakibatkan bobot biji per tanaman juga berat. Genotipe nomor 7.199.4 merupakan genotipe yang memiliki bobot biji per tanaman 39,6 g atau 3,9 ton/ha, dibandingkan dengan 13 nomor genotipe yang diuji dan varietas Wilis sebagai pembandingnya genotipe nomor 7.199.4 merupakan yang terberat, sedangkan dengan pembanding varietas Mlg 2521 terdapat satu nomor genotipe yang tidak lebih unggul dari 13 genotipe yang diuji lainnya karena genotipe nomor 7.44.3 memiliki bobot biji per tanaman hanya 25,24 g atau sekitar 2,52 ton/ha.

Berdasarkan hasil penelitian ini, didapatkan genotipe - genotipe harapan yang lebih unggul dari kedua varietas pembanding. Genotipe - genotipe generasi $\mathrm{F}_{6}$ yang terpilih tersebut merupakan benih kedelai yang unggul dan akan digunakan seorang pemulia tanaman untuk meneruskan penelitian selanjutnya.

\section{KESIMPULAN}

Hasil penelitian ini terdapat satu nomor harapan, yaitu nomor 7.199.4 yang memiliki bobot biji per tanaman $39,16 \mathrm{~g}$ atau 3,92 ton/ha yang melebihi bobot biji per tanaman tetua Wilis, selain itu nomor 7.199.4 memiliki umur berbunga 47,50 hst, umur panen 109,00 hst, tinggi tanaman $95,17 \mathrm{~cm}$, jumlah cabang 5,42 buah, total jumlah polong 172,00 buah dan memiliki bobot 100 butir $11,31 \mathrm{~g}$.

\section{DAFTAR PUSTAKA}

Adie, M.M dan A. Krisnawati. 2007. Peluang peningkatan kualitas biji kedelai. Prosiding. Risalah Seminar. 23 November 2008. Badan Litbang Pertanian, hlm: 216-230.

Asadi, Soemartono, M. Woerjono, dan H. Jumanto. 2003. Kendali genetik ketahanan kedelai terhadap penyakit virus kerdil (Soybean stunt virus). Zuriat 14 (2): 1-11.

Arsyad, D.M., M. M Adie, dan H. Kuswantoro. 2007. Perakitan varietas unggul kedelai spesifik agroekologi, hlm: 205-228. Dalam: Sumarno, Suyamto, A. Widjono, Hermanto, dan H. Kasim (Eds.). Kedelai: Teknik Produksi dan
Pengembangan. Pusat Penelitian dan Pengembangan Tanaman Pangan badan Penelitian dan Pengembangan Pertanian. Bogor.

Badan Pusat Statistik. 2013. Tanaman pangan Produksi Tanaman Kedelai Provinsi Indonesia. Available online at http://bps.go.id/tnmn_pgn.php?kat=3, [19 Oktober 2013].

Barmawi, M., H.M.Akin, dan N. Sa'diyah 2013. Perakitan varietas unggul kedelai yang tahan terhadap Soybean stunt virus dan Soybean mosaic virus. Laporan Akhir Penelitian Strategis Nasional (tahun ke-2). Universitas Lampung. Bandar Lampung.

Evita. 2010. Respon tanaman kacang tanah (Arachis hypogea L.) terhadap kecaman air. Buletin Agronomi. 3(7): 15-20.

Gardner, F. P., R. B. Pearce, dan R. L. Mitchell. 1991. Fisiologi Tanaman Budidaya (terjemahan). Universitas Indonesia Press. Jakarta. $428 \mathrm{hlm}$.

Kementan. 2013. Guna memenuhi kebutuhan industri tahu-tempe, maka dilakukan impor dimana sampai dengan bulan September 2013 tercatat sebesar 1,2 juta ton. Available online at http:// www.tribunnews.com/bisnis/2013/12/30/tahun2013-kedelai-alami-defisit-13-juta-ton, [16 Oktober 2014].

Ohorella, Z. 2011. Respon pertumbuhan dan produksi tanaman kedelai pada sistem olah tanah yang berbeda. Jurnal Agronomika. Vol 1 (2): $92-$ 98.

Pandiangan, M. B. S. P. K. 2012. Uji daya hasil kedelai (Glycine $\max ($ L.) Merril) berdaya hasil tinggi di kampung Sidey Makmur SP 11 Manokwari. Skripsi. Universitas Negeri Papua. Manokwari.

Sari, Y. 2013. Estimasi keragaman dan heritabilitas karakterAgronomi (Glycine max [L.] Merrill) famili $F_{3}$ hasil persilangan antara Wilis $x \mathrm{Mlg}$ 2521. Skripsi. Universitas Lampung. Bandar Lampung.

Siagian, C.R. 2014. Korelasi dan analisis lintas karakter Agronomi kedelai (Glycine max [L.] Merill) hasil persilangan Wilis dan Mlg 2521. Skripsi. Universitas Lampung. Bandar Lampung.

Sumpena, U., Y. Kusandriani, dan Luthfi. 2013. Uji daya hasil sembilan galur harapan kacang merah di Jawa Barat. Jurnal Agrotropika. 18(1): 12 -15 . 
Susanto, G. W. A. 2004. Variasi genetik karakteristik kuantitatif galur-galur kedelai. Dukungan Pemuliaan terhadap Industri Perbenihan pada Era Pertanian Kompetatif. Prosiding Lokakarya. Perhimpunan Ilmu Pemuliaan Indonesia VII.
Yantama, E. 2012. Keragaman dan Hertabilitas Karakter Agronomi Kedelai (Glycine max [L.] Merril) Generasi $F_{2}$ Hasil Persilangan Wilis dan Malang 2521. Skripsi. Universitas Lampung. Bandar Lampung. 